\title{
ANALISIS PERATURAN DAERAH TENTANG TANGGUNG JAWAB SOSIAL PERUSAHAAN DI TENGAH IKLIM KEMUDAHAN BERUSAHA DALAM PERSPEKTIF TEORI PERUNDANG-UNDANGAN
}

\author{
(Analysis of Regional Regulation on Corporate Social Responsibility in The Middle of Ease of Doing \\ Business Climate in Perspective of Legislation Theory)
}

\author{
Budi S.P. Nababan \\ Kantor Wilayah Kementerian Hukum dan HAM Sumatera Utara \\ Jalan Putri Hijau No. 4 Medan \\ Email: budinababan.bn@gmail.com
}

Naskah diterima: 16 Agustus 2018; revisi: 31 Oktober 2018; disetujui: 5 November 2018

\begin{abstract}
Abstrak
Semangat Pemerintah untuk mendorong kemudahan berusaha kurang didukung oleh Pemerintahan Daerah seperti masih banyaknya Pemerintah Daerah yang menetapkan peraturan daerah yang mengatur mengenai tanggung jawab sosial di lingkungan perusahaan. Dengan harapan akan meningkatkan pendapatan daerah, daerah berlomba-lomba mengatur hal tersebut dalam peraturan daerahnya. Dalam konteks ini, keberadaan peraturan daerah tentang tanggung jawab sosial ini di tengah iklim kemudahan berusaha serta kedudukannya dalam peraturan perundang-undangan merupakan topik yang menarik untuk menjadi obyek kajian. Melalui penelitian hukum normatif dengan pendekatan undang-undang, ditemukan bahwa peraturan daerah yang mengatur mengenai tanggung jawab sosial ini hanya akan menimbulkan ekonomi biaya tinggi sehingga akan menghambat laju investasi di daerah, sehingga sejatinya tidak perlu untuk dibuat dalam bentuk peraturan daerah yang secara khusus mengatur mengenai tanggung jawab sosial perusahaan. Selain itu mengenai kedudukan peraturan daerah ini dalam peraturan perundang-undangan adalah bertentangan dengan peraturan lebih tinggi dan harus dibatalkan sesuai dengan mekanisme yang berlaku.
\end{abstract}

Kata Kunci: kemudahan berusaha, otonomi daerah, peraturan daerah, tanggung jawab sosial perusahaan

\begin{abstract}
The spirit of the Government to encourage the ease of doing business is not gaining enough support from the local governments. For example, there are still many local governments that stipulate regional regulation on corporate social responsibility (CSR). Hoping that it will increase regional income, regions compete to regulate corporate social responsibility through regional regulation. In this context, the existence of the regional regulation on CSR amid the ease of doing business climate and its position within the national legislation is interesting to be examined. Through normative legal research method with a statute approach, it is found that: the regional regulation on CSR will cause a high cost economy that will hamper the rate of investment in the region, so there is no need to make a regional regulation on CSR; the position of the regional regulation on CSR within thenational legislation is contrary to the higher regulations and must be cancelled in accordance with the applicable mechanism.
\end{abstract}

Keywords: ease of doing business, regional autonomy, regional regulation, corporate social responsibility 


\section{A. Pendahuluan}

Kemudahan berusaha lease of doing business) adalah survey global yang dilakukan sejak tahun 2012 oleh International Finance Corporation terhadap tidak kurang 180 negara di seluruh dunia. Survey dilakukan untuk mengukur seberapa kondusif kerangka regulasi dan kebijakan yang ada di suatu negara terkait dalam hal dimulainya berusaha dan kegiatan suatu usaha lokal. Survey menggunakan metodologi standar untuk melihat respon sistem hukum terhadap situasi yang relatif sama (situasi kemudahan berusaha), terlepas dari ragam sistem hukum yang ada di masingmasing negara yang disurvey. ${ }^{1}$ Meskipun peringkat Indonesia masih jauh dari harapan dibandingkan dengan negara-negara tetangga, namun dalam laporan terbaru The World Bank, peringkat Indonesia dalam ease of doing business naik dari posisi 91 pada tahun 2017 ke posisi 72 untuk tahun $2018 .^{2}$ Kenaikan posisi dalam ease of doing business tersebut merupakan kerja keras Pemerintah melalui sejumlah paket kebijakan, pembatalan Perda bermasalah, upaya deregulasi dan debirokratisasi.

Namun semangat Pemerintah untuk mendorong ease of doing business kurang didukung oleh Pemerintahan Daerah ${ }^{3}$ dalam menyusun Produk Hukum Daerah ${ }^{4}$ yang tidak mendukung kemudahan berusaha. Hal ini dapat dilihat masih ada Pemerintahan Daerah menyusun rancangan Perda mengenai tanggung jawab sosial lingkungan perusahaan (corporate social responsibility) (Perda CSR) dalam Program Pembentukan Perda ${ }^{5}$, seperti Kabupaten Serdang Bedagai ${ }^{6}$ dan Kabupaten Labuhanbatu $^{7}$ di Sumatera Utara. Bahkan beberapa daerah telah menetapkan Perda CSR, seperti: Perda Provinsi Jawa Timur Nomor 2 Tahun 2017, Perda Kota Banjarmasin Nomor 14 Tahun 2016, Perda Kota Makassar Nomor 2 Tahun 2016, Perda Kota Surakarta Nomor 2

1 Tentang Kemudahan Berusaha, http://pembaruanperadilan.net/kemudahanberusaha/ (diakses 13 Agustus 2018).

2 Naik 19 Peringkat, Kemudahan Berusaha RI Di Atas China dan India, https://finance.detik.com/berita-ekonomibisnis/d-3708649/naik-19-peringkat-kemudahan-berusaha-ri-di-atas-china-dan-india, (diakses 13 Agustus 2018).

3 Pemerintahan Daerah menurut Pasal 1 angka 2 Undang-Undang Nomor 23 Tahun 2014 tentang Pemerintahan Daerah Daerah sebagaimana telah diubah beberapa kali terakhir dengan Undang-Undang Nomor 9 Tahun 2015 tentang Perubahan Kedua Undang-Undang Nomor 23 Tahun 2014 tentang Pemerintahan Daerah adalah penyelenggaraan urusan pemerintahan oleh pemerintah daerah dan dewan perwakilan rakyat daerah menurut asas otonomi dan tugas pembantuan dengan prinsip otonomi seluas-luasnya dalam sistem dan prinsip Negara Kesatuan Republik Indonesia sebagaimana dimaksud dalam Undang-Undang Dasar Negara Republik Indonesia Tahun 1945. Lihat juga Pemerintahan Daerah dalam Pasal angka 2 Undang-Undang Nomor 33 Tahun 2004 tentang Perimbangan Keuangan Antara Pemerintah Pusat dan Pemerintahan Daerah.

4 Produk Hukum Daerah menurut Pasal 1 angka 19 Peraturan Menteri Dalam Negeri Nomor 80 Tahun 2015 tentang Pembentukan Produk Hukum Daerah adalah produk hukum berbentuk peraturan meliputi perda atau nama lainnya, perkada, PB KDH, peraturan DPRD dan berbentuk keputusan meliputi keputusan kepala daerah, keputusan DPRD, keputusan pimpinan DPRD dan keputusan badan kehormatan DPRD.

5 Program Pembentukan Perda menurut Pasal 1 angka 13 Peraturan Menteri Dalam Negeri Nomor 80 Tahun 2015 tentang Pembentukan Produk Hukum Daerah adalah instrumen perencanaan program pembentukan perda provinsi dan perda kabupaten/kota yang disusun secara terencana, terpadu, dan sistematis.

6 Program Pembentukan Peraturan Daerah Kabupaten Serdang Bedagai Tahun 2017, ppid.serdangbedagaikab. go.id/front/dokumen/download/300003019 (diakses 4 Oktober 2018).

7 Keputusan DPRD Kabupaten Labuhanbatu Nomor 3/DPRD/ Tahun 2018 tentang Program Pembentukan Peraturan Daerah Kabupaten Labuhanbatu Tahun 2018. 
Tahun 2015, Perda Kota Magelang Nomor 11 melalui Putusan MK Nomor 137/PUU-XIII/2015 Tahun 2017, Perda Kabupaten Buleleng Nomor 7 Tahun 2017, Perda Kota Jambi Nomor 1 Tahun 2016, Perda Provinsi Kalimantan Barat Nomor 4 Tahun 2016. Padahal Perda CSR termasuk dalam 1765 Perda yang dibatalkan Pemerintah tahun $2016^{8}$, sebelum kewenangan pembatalan Perda dipangkas Mahkamah Konstitusi (MK) tanggal 5 April 2017 dan Putusan MK Nomor 56/PUU-XIV/2016 tanggal 14 Juni $2017 .{ }^{9}$ Ribuan Perda tersebut bermasalah karena menghambat pertumbuhan ekonomi daerah, memperpanjang jalur birokrasi, menghambat proses perizinan dan investasi, menghambat kemudahan berusaha dan bertentangan dengan

8 Dari 1765 perda dan peraturan kepala daerah dibatalkan Kementerian Dalam Negeri dalam Daftar Perda/ Perkada Dan Peraturan Menteri Dalam Negeri Yang Dibatalkan/Revisi, terdapat 16 perda mengenai CSR, yaitu: Perda Kabupaten Gunung Mas Nomor 4 Tahun 2015, Perda Kabupaten Barito Utara Nomor 3 Tahun 2015, Perda Kabupaten Mojokerto Nomor 7 Tahun 2015, Perda Kabupaten Mukomuko Nomor 3 Tahun 2014, Perda Kabupaten Pandeglang Nomor 8 Tahun 2011, Perda Kabupaten Bogor Nomor 6 Tahun 2013, Perda Kota Bekasi Nomor 6 Tahun 2015, Perda Kota Cimahi Nomor 10 Tahun 2013, Perda Provinsi Kalimantan Timur Nomor 3 Tahun 2013, Perda Kabupaten Tanjung Jabung Timur Nomor 13 Tahun 2013, Perda Kabupaten Maluku Tenggara Barat Nomor 9 Tahun 2014, Perda Kabupaten Bengkayang Nomor 11 Tahun 2014, Perda Provinsi Sulawesi Tenggara Nomor 7 Tahun 2014, Perda Provinsi Kalimantan Tengah Nomor 11 Tahun 2012, dan Perda Kota Batam Nomor 2 Tahun 2012. Diolah dari Daftar Perda/Perkada Dan Peraturan Menteri Dalam Negeri Yang Dibatalkan/Revisi, https://www.kemendagri.go.id/media/filemanager/2016/06/21/b/a/batal_perda_21_juni_2016.pdf (diakses 3 Oktober 2018). Sebenarnya perihal pembatalan perda bukanlah hal baru, sebagaimana dalam penelitian Taufik H Simatupang yang mengemukakan sejumlah fakta empirik bahwa:

1. pada tahun tahun 2002-2009 sudah ada 1879 perda yang dibatalkan.

2. pada tahun 2010 dari klarifikasi 3000 perda ditemukan 407 perda yang bermasalah.

3. pada tahun 2011 dari klarifikasi 9000 perda ditemukan 351 perda yang bermasalah.

4. pada tahun 2012 dari klarifikasi 3000 perda ditemukan 173 perda yang bermasalah.

5. pada tahun 2013 dari klarifikasi 2500 perda ditemukan 215 perda yang bermasalah.

6. pada tahun 2014 dari klarifikasi 2500 perda ditemukan 354 perda yang bermasalah.

7. pada tahun 2016 sebanyak 1765 perda dan peraturan kepala daerah dibatalkan.

Taufik H Simatupang, "Peran Perancang Peraturan Perundang-Undangan Kantor Wilayah Kementerian Hukum dan HAM Dalam Rangka Harmonisasi Peraturan Daerah", Jurnal Ilmiah Kebijakan Hukum Vol. 11 No. 1 Maret (2017): 14-15.

9 Sebelum lahirnya Putusan MK Nomor 137/PUU-XIII/2015 tanggal 5 April 2017, kewenangan untuk membatalkan perda merupakan kewenangan Pemerintah yang dilaksanakan oleh Kementerian Dalam Negeri. Oleh MK dalam amar putusannya dinyatakan bahwa frasa "peraturan daerah kabupaten/kota dan" dalam ketentuan Pasal 251 ayat (2) dan ayat (4) UU 23/2014, frasa "peraturan daerah kabupaten/kota dan/atau" dalam Pasal 251 ayat (3) UU 23/2014, dan frasa "penyelenggara pemerintahan daerah kabupaten/kota tidak dapat menerima keputusan pembatalan perda kabupaten/kota dan" dalam ketentuan Pasal 251 ayat (7) dan ayat (8) UU 23/2014 bertentangan dengan Undang-Undang Dasar Negara Republik Indonesia Tahun 1945 dan tidak mempunyai kekuatan hukum mengikat. Dengan demikian baik Menteri Dalam Negeri maupun gubernur tidak lagi berwenang membatalkan perda kabupaten/kota, sehingga pembatalan perda harus dilakukan melalui mekanisme judicial review di Mahkamah Agung. Putusan ini juga dilengkapi/diperkuat dengan Putusan MK Nomor 56/PUU-XIV/2016 tanggal 14 Juni 2017 yang menyatakan bahwa pembatalan perda kabupaten/kota melalui executive review adalah bertentangan dengan Undang-Undang Dasar Negara Republik Indonesia Tahun 1945. Oleh karena dalam Pasal 251 ayat (1) UU 23/2014 mengatur mengenai pembatalan perda provinsi juga melalui executive review, maka MK berpendapat Pasal 251 ayat (1) UU 23/2014 sepanjang frasa "peraturan daerah provisi dan"bertentangan dengan Undang-Undang Dasar Negara Republik Indonesia Tahun 1945 dengan pertimbangan hukum seperti dalam Putusan MK Nomor 137/PUU-XIII/2015 tanggal 5 April 2017. Dengan lahirnya kedua putusan MK ini maka Pemerintah tidak lagi memiliki kewenangan untuk melakukan pembatalan perda, baik peraturan daerah provinsi maupun perda kabupaten/kota. 
peraturan perundang-undangan yang lebih tinggi. ${ }^{10}$

Pemerintahan Daerah ketika menyusun Perdadiselimutisemangatotonomidaerah untuk memperoleh sebanyak mungkin Pendapatan Daerah, yaitu hak Pemerintah Daerah yang diakui sebagai penambah nilai kekayaan bersih dalam periode tahun bersangkutan. ${ }^{11}$ Padahal konsideran menimbang huruf $b$ Undang-Undang Nomor 23 Tahun 2014 tentang Pemerintahan Daerah sebagaimana telah diubah beberapa kali terakhir dengan Undang-Undang Nomor 9 Tahun 2015 tentang Perubahan Kedua Undang-Undang Nomor 23 Tahun 2014 tentang Pemerintahan Daerah (UU 23/2014) menyebutkan: "Bahwa penyelenggaraan pemerintahan daerah diarahkan untuk mempercepat terwujudnya kesejahteraan masyarakat melalui peningkatan pelayanan, pemberdayaan, dan peran serta masyarakat, serta peningkatan daya saing daerah dengan memperhatikan prinsip demokrasi, pemerataan, keadilan, dan kekhasan suatu daerah dalam sistem Negara Kesatuan Republik Indonesia". Bila rumusan konsideran UU 23/2014 ini dihubungkan dengan semangat Pemerintah untuk menciptakan iklim kemudahan berusaha, maka Pemerintahan Daerah seharusnya mendukung kebijakan tersebut dengan menyusun produk hukum daerah yang mendukung kemudahan berusaha, bersinergi dengan regulasi pusat dalam kesatuan sistem hukum nasional.

Dalam peraturan perundang-undangan, klausul yang setidaknya mirip dengan CSR pertama sekali diatur dalam Keputusan Menteri BUMN Nomor Kep-236/MBU/2003 tanggal 17 Juni 2003 tentang Program Kemitraan BUMN Dengan Usaha Kecil dan Program Bina Lingkungan (KepmenBUMN 236/MBU/2003) ${ }^{12}$ yang mengatur mulai dari besaran dana hingga tata cara pelaksanaan program kemitraan dan program bina lingkungan. Kemudian CSR secara eksplisit dalam Undang-Undang Nomor 40 Tahun 2007 tentang Perseroan Terbatas (UU 40/2007) dan Peraturan Pemerintah Nomor 47 Tahun 2012 tentang Tanggung Jawab Sosial dan Lingkungan Perseroan Terbatas (PP 47/2012), serta secara implisit disisipkan dalam berbagai undang-undang sektoral seperti UndangUndang Nomor 22 Tahun 2001 tentang Minyak Gas Bumi (UU 22/2001), Undang-Undang Nomor 25 Tahun 2007 tentang Penanaman Modal (UU 25/2007), Undang-Undang Nomor 32 Tahun 2009 tentang Perlindungan dan Pengelolaan Lingkungan Hidup (UU 32/2009) dan Undang-Undang Nomor 21 Tahun 2014 tentang Panas Bumi (UU 21/2014). Dalam peraturan perundang-undangan tersebut tidak

10 Presiden Umumkan Pembatalan 3.143 Perda Bermasalah, https://www.kemendagri.go.id/blog/4334-PresidenUmunkan-Pembatalan-3143-Perda-Bermasalah, (diakses 3 Oktober 2018).

11 Lihat lebih lanjut Pasal 1 angka 13 Undang-Undang Nomor 33 Tahun 2004 tentang Perimbangan Keuangan Antara Pemerintah Pusat dan Pemerintahan Daerah.

12 Keputusan Menteri BUMN Nomor Kep-236/MBU/2003 ini kemudian diganti dengan Peraturan Menteri Negara BUMN Nomor PER-05/MBU/2007 tentang Program Kemitraan BUMN Dengan Usaha Kecil dan Program Bina Lingkungan sebagaimana telah diubah beberapa kali terakhir dengan Peraturan Menteri Negara BUMN Nomor PER-08/MBU/2013 Tahun 2013 tentang Perubahan Keempat Atas Peraturan Menteri Negara BUMN Nomor PER-05/MBU/2007 tentang Program Kemitraan BUMN Dengan Usaha Kecil dan Program Bina Lingkungan. Kemudian diganti dengan Peraturan Menteri BUMN Nomor PER-07/MBU/05/2015 tentang Program Kemitraan BUMN Dengan Usaha Kecil dan Program Bina Lingkungan. Kemudian selang 1 (satu) bulan, diganti lagi dengan Peraturan Menteri BUMN Nomor PER-09/MBU/07/2015 tentang Program Kemitraan BUMN Dengan Usaha Kecil dan Program Bina Lingkungan. 
mendelegasikan kepada daerah untuk mengatur CSR.

CSR erat kaitannya dengan anggaran yang diperhitungkan sebagai biaya perusahaan yang akan disalurkan dengan memperhatikan kepatutan dan kewajaran kepada masyarakat. ${ }^{13}$ Namun keberadaan CSR disalahartikan oleh Pemerintahan Daerah dengan menjadikan CSR sebagai alternatif sumber pembiayaan pembangunan daerah, seperti di Kota Bandung $^{14}$, Kota Jakarta ${ }^{15}$ dan Kabupaten Kotabaru. ${ }^{16}$ Bahkan di Kabupaten Bengkulu Utara CSR dijadikan komponen pendapatan daerah sebagaimana disampaikan Bupati Bengkulu Utara dalam nota pengantar keuangan RAPBD 2017 yang mengatakan perlu dibuat Perda CSR untuk peningkatan Pendapatan Asli Daerah (PAD). ${ }^{17}$

Padahal Undang-Undang Nomor 33 Tahun
2004 tentang Perimbangan Keuangan Antara Pemerintah Pusat dan Pemerintahan Daerah (UU 33/2004) menyebutkan jika sumbersumber pendanaan pelaksanaan Pemerintahan Daerah berasal dari PAD, dana perimbangan, pinjaman daerah, dan lain-lain pendapatan yang sah. ${ }^{18}$ PAD, dana perimbangan, dan lain-lain pendapatan inilah yang merupakan Pendapatan Daerah. ${ }^{19}$ PAD bersumber dari: a. pajak daerah; b. retribusi daerah; c. hasil pengelolaan kekayaan daerah yang dipisahkan; dan d. lain-lain PAD yang sah. Lain-lain PAD yang sah meliputi: a. hasil penjualan kekayaan daerah yang tidak dipisahkan; b. jasa giro; c. pendapatan bunga; d. keuntungan selisih nilai tukar rupiah terhadap mata uang asing; dan e. komisi, potongan, ataupun bentuk lain sebagai akibat dari penjualan dan/atau pengadaan barang dan/atau jasa oleh daerah. ${ }^{20}$

13 Lihat lebih lanjut Pasal 5 Peraturan Pemerintah Nomor 47 Tahun 2012 tentang Tanggung Jawab Sosial dan Lingkungan Perseroan Terbatas.

14 Pakai Dana CSR, Ridwan Kamil Diingatkan Soal Serapan APBD, https://nasional.tempo.co/read/670014/pakaidana-csr-ridwan-kamil-diingatkan-soal-serapan-apbd/full\&view=ok, (diakses 4 Oktober 2018).

15 Memanjakan Warga Jakarta Dengan Produk-Produk CSR, https://megapolitan.kompas.com/ read/2015/09/05/06030031/Memanjakan.Warga.Jakarta.dengan.Produk-produk.CSR, (diakses 4 Oktober 2018).

16 Dalam penelitian Hasa Noor Hasadi et. al., salah satu program CSR berdasarkan Pasal 11 ayat (1) Perda Kabupaten Nomor 19 Tahun 2013 program/kegiatan pemerintah daerah yang tidak terakomodir melalui APBD/APBN dapat berupa: kegiatan penelitian dan pengembangan; pembangunan fasilitas publik; dan pengembangan organisasi kemasyarakatan, kepemudaan, keagamaan, seni dan budaya. Hasa Noor Hasadi et al., "Pengaruh Program Corporate Social Responsibility (CSR) PT. Sebuku Iron Lateritic Ores (PT. SILO) Terhadap Tingkat Pendapatan Masyarakat Di Desa Tanjung Mangkuk, Kecamatan Pulau Sebuku, Kabupaten Kotabaru", JPG (Jurnal Pendidikan Geografi) Vol. 1 No. 1 Juli (2014): 59.

17 Pemkab Garap Perda CSR, http://pedomanbengkulu.com/2016/12/pemkab-garap-perda-csr/, (diakses 2 Oktober 2018).

18 Penjelasan Undang-Undang Nomor 33 Tahun 2004 tentang Perimbangan Keuangan Antara Pemerintah Pusat dan Pemerintahan Daerah.

19 Pasal 5 ayat (2) Undang-Undang Nomor 33 Tahun 2004 tentang Perimbangan Keuangan Antara Pemerintah Pusat dan Pemerintahan Daerah. Bandingkan dengan pendapatan daerah menurut Pasal 285 ayat (1) UndangUndang Nomor 23 Tahun 2014 tentang Pemerintahan Daerah Daerah sebagaimana telah diubah beberapa kali terakhir dengan Undang-Undang Nomor 9 Tahun 2015 tentang Perubahan Kedua Undang-Undang Nomor 23 Tahun 2014 tentang Pemerintahan Daerah.

20 Pasal 6 Undang-Undang Nomor 33 Tahun 2004 tentang Perimbangan Keuangan Antara Pemerintah Pusat dan Pemerintahan Daerah. Bandingkan dengan Pasal 285 ayat (1) huruf a dan Pasal 195 Undang-Undang Nomor 23 Tahun 2014 tentang Pemerintahan Daerah Daerah sebagaimana telah diubah beberapa kali terakhir dengan Undang-Undang Nomor 9 Tahun 2015 tentang Perubahan Kedua Undang-Undang Nomor 23 Tahun 2014 tentang Pemerintahan Daerah. 
Maka berkaitan dengan keberadaan Perda CSR ini menjadi topik bahasan yang menarik untuk dikaji bagaimana keberadaan Perda CSR di tengah iklim kemudahan berusaha dan bagaimana kedudukan Perda CSR dalam peraturan perundang-undangan.

\section{B. Metode Penelitian}

Metode yang digunakan dalam tulisan ini adalah metode penelitian hukum normatif seperti yang dikemukakan oleh Soerjono Soekanto dan Sri Mamudji ${ }^{21}$, sebab penelitian dalam tulisan ini dilakukan terhadap data sekunder berupa bahan hukum primer yaitu peraturan perundang-undangan dan putusan MK yang diperoleh dari perpustakaan maupun dari internet, sebagai berikut:

a. Undang-Undang Nomor 22 Tahun 2001 tentang Minyak Gas Bumi;

b. Undang-Undang Nomor 33 Tahun 2004 tentang Perimbangan Keuangan Antara Pemerintah Pusat dan Pemerintahan Daerah;

c. Undang-Undang Nomor 25 Tahun 2007 tentang Penanaman Modal;

d. Undang-Undang Nomor 40 Tahun 2007 tentang Perseroan Terbatas;

e. Undang-Undang Nomor 32 Tahun 2009 tentang Perlindungan dan Pengelolaan Lingkungan Hidup; f. Undang-Undang Nomor 12 Tahun 2011 tentang Pembentukan Peraturan Perundangundangan;

g. Undang-Undang Nomor 23 Tahun 2014 tentang Pemerintahan Daerah sebagaimana telah diubah beberapa kali terakhir dengan Undang-Undang Nomor 9 Tahun 2015 tentang Perubahan Kedua Atas UndangUndang Nomor 23 Tahun 2014 tentang Pemerintahan Daerah;

h. Undang-Undang Nomor 21 Tahun 2014 tentang Panas Bumi;

i. Putusan MK Nomor 53/PUU-VI/2008;

j. Peraturan Pemerintah Nomor 47 Tahun 2012 tentang Tanggung Jawab Sosial dan Lingkungan Perseroan Terbatas;

k. Peraturan Menteri BUMN Nomor PER-09/ MBU/07/2015 tentang Program Kemitraan BUMN Dengan Usaha Kecil dan Program Bina Lingkungan; serta

I. Peraturan Menteri Dalam Negeri Nomor 80 Tahun 2015 tentang Pembentukan Produk Hukum Daerah.

Adapun pendekatan analisis yang digunakan dalam tulisan ini adalah pendekatan undangundang (statute approach) sebagaimana yang dikemukakan oleh Peter Mahmud Marzuki22, sebab menelaah semua data sekunder berupa bahan hukum primer yang telah disebutkan sebelumnya.

Sedangkan sifat penelitian yang digunakan dalam tulisan ini adalah preskriptif sebagaimana 
juga dikemukakan Peter Mahmud Marzuki' ${ }^{23}$, sebab yang dihasilkan dalam penelitian ini bukanlah asas hukum yang baru atau teori hukum yang baru, melainkan sebuah argumentasi hukum mengenai keberadaan Perda CSR.

\section{Pembahasan}

\section{Dasar Hukum Keberadaan Perda mengenai CSR di tengah Iklim Kemudahan Berusaha}

Menurut World Bank, CSR is the commitment of business to contribute to sustainable economic development working with employees and their representatives the local community and society at large to improve the quality of life, in ways that are both good for business and good for development. ${ }^{24}$ Menurut Kamar Dagang Industri, tanggung jawab sosial perusahaan sebagai tanggung jawab suatu organisasi atas dampak dari keputusan dan aktivitasnya terhadap masyarakat dan lingkungan melalui perilaku yang transparan dan etis; yang konsisten dengan pembangunan berkelanjutan dan kesejahteraan masyarakat; memperhatikan kepentingan dari para stakeholder; sesuai hukum yang berlaku dan konsisten dengan norma-norma internasional; terintegrasi di seluruh aktivitas organisasi. ${ }^{25}$
Sedangkan dalam peraturan perundangundangan, dalam UU 25/2007 disebutkan bahwa Tanggung Jawab Sosial Perusahaan adalah tanggung jawab yang melekat pada setiap perusahaan penanaman modal untuk tetap menciptakan hubungan yang serasi, seimbang, dan sesuai dengan lingkungan, nilai, norma, dan budaya masyarakat setempat ${ }^{25}$ dan menurut UU 40/2007, Tanggung Jawab Sosial dan Lingkungan adalah komitmen Perseroan untuk berperan serta dalam pembangunan ekonomi berkelanjutan guna meningkatkan kualitas kehidupan dan lingkungan yang bermanfaat, baik bagi Perseroan sendiri, komunitas setempat, maupun masyarakat pada umumnya. ${ }^{26}$

Dalam dekade terakhir wacana CSR di Indonesia semakin mengemuka seiring dengan kerusakan lingkungan hidup. ${ }^{27}$ CSR mulai dipopulerkan pada tahun 1953 dengan terbitnya buku Howard R. Bowen yang berjudul "Social Responsibilities of the Businessman", yang periode selanjutnya isu-isu CSR terus berkembang pada tahun 1960-an yang dilandasi oleh permasalahan kemiskinan dan keterbelakangan yang mulai mendapat perhatian lebih luas dari berbagai kalangan. ${ }^{28}$ Perkembangan CSR tidak terlepas

23 Menurut Peter Mahmud Marzuki, dalam memberikan preskripsi mengenai apa yang seharusnya merupakan esensial dari penelitian hukum, baik untuk keperluan praktik hukum maupun untuk keperluan akademis yang berpegang pada karakteristik ilmu hukum sebagai ilmu terapan, preskripsi yang diberikan di dalam kegiatan penelitian hukum harus dapat dan mungkin untuk diterapkan. Oleh karena itu yang dihasilkan oleh penelitian hukum, sekalipun bukan asas hukum yang baru atau teori baru, paling tidak argumentasi baru. Peter Mahmud Marzuki, Ibid., hlm. 251.

24 Badan Pembinaan Hukum Nasional Departemen Hukum dan HAM, Tanggung Jawab Sosial Perusahaan, (Jakarta: Departemen Hukum dan HAM, 2009), hlm. 7.

25 Badan Pembinaan Hukum Nasional Departemen Hukum dan HAM, Ibid., hlm. 8.

26 Penjelasan Pasal 15 huruf b Undang-Undang Nomor 25 Tahun 2007 tentang Penanaman Modal.

27 Pasal 1 angka 3 Undang-Undang Nomor 40 Tahun 2007 tentang Perseroan Terbatas.

28 M. Azis Firdaus, "Kemitraan Pemerintah Dan Swasta Dalam Pembangunan Sumber Daya Manusia Melalui Implementasi CSR", dalam Proceeding Simposium Nasional Otonomi Daerah: Best Practices Dalam Penyelenggaraan Otonomi Daerah, (Serang: FISIP Untirta dan Laboratorium Administrasi Negara FISIP Untirta, 2011), hlm. 30. 
dari konsep pembangunan berkelanjutan (sustainability development) ${ }^{29}$, namun konsep CSR tidaklah sama dengan karikatif (charity) ataupun kedermawanan (philanthropy) yang lebih spontan pemberiannya oleh perusahaan dan kurang memiliki efek jangka panjang bagi masyarakat dalam arti pemberdayaan mereka secara ekonomi, sosial, dan budaya. ${ }^{30}$ Sebenarnya jika ditelusuri secara mendalam, konsep CSR sudah dikenal dalam hukum adat di Indonesia, yaitu berupaya mencegah terjadinya dishamonisasi, dalam arti selalu menjaga keseimbangan alam (konsep magis religius). Konsep magis religius dalam hukum adat inilah mirip dengan konsep CSR.

Telah disampaikan sebelumnya jika CSR pertama sekali diatur oleh pemerintah dalam KepmenBUMN 236/MBU/2003, dimana Kepmen ini telah diganti dan bahkan beberapa kali mengalami perubahan, adapun kini yang berlaku adalah Peraturan Menteri BUMN Nomor PER-09/MBU/07/2015 tentang Program Kemitraan BUMN Dengan Usaha Kecil dan Program Bina Lingkungan (PermenBUMN 09/ $\mathrm{MBU} / 07 / 2015) .^{31}$ Sedangkan untuk badan usaha lain selain BUMN seperti: koperasi, CV, firma, dan usaha dagang juga mempunyai kewajiban CSR, secara tersirat dalam Pasal 15, Pasal 16, dan Pasal 34 UU 25/2007.

Selain diatur dalam PermenBUMN 09/ MBU/07/2015 dan UU 25/2007, kegiatan yang konsepnya sama dengan CSR juga diatur dalam beberapa undang-undang, seperti UU 22/200132 serta UU 32/2009 ${ }^{33}$, UU 21/2014..$^{34}$ Kemudian secara tegas CSR diatur dalam UU 40/2007 ${ }^{35}$, setidaknya dengan 2 (dua) argumen: pertama, karena keprihatinan Pemerintah atas praktik korporasi yang mengabaikan aspek sosial lingkungan yang mengakibatkan kerugian di masyarakat, kedua sebagai wujud upaya entitas negara dalam penentuan standar aktivitas sosial lingkungan yang sesuai dengan konteks nasional maupun lokal. ${ }^{36}$

Di dalam Pasal 74 ayat (4) UU 40/2007 tersebut, Pemerintah diberi amanat untuk membentuk PP yang mengatur CSR yaitu melalui PP 47/2012 yang bertujuan mewujudkan pembangunan ekonomi berkelanjutan guna meningkatkan kualitas kehidupan dan lingkungan yang bermanfaat bagi komunitas setempat dan masyarakat pada umumnya maupun Perseroan itu sendiri dalam rangka terjalinnya hubungan Perseroan yang serasi,

Rahmatullah, Op. cit, hlm. 198.

30 Badaruddin, "Implementasi Tanggung Jawab Sosial Perusahaan Terhadap Masyarakat Melalui Pemanfaatan Potensi Modal Sosial: Alternatif Pemberdayaan Masyarakat Miskin Di Indonesia", Pidato Pengukuhan Jabatan Guru Besar Tetap dalam Bidang Ilmu Sosiologi Perkotaan pada Fakultas Ilmu Sosial dan Ilmu Politik Universitas Sumatera Utara, 12 April 2008, (Medan: Universitas Sumatera Utara, 2008), hlm. 2.

31 Dalam Pasal 1 angka 6 dan angka 7 Peraturan Menteri Negara BUMN Nomor PER-09/MBU/07/2015 tentang Program Kemitraan Badan Usaha Milik Negara Dengan Usaha Kecil dan Program Bina Lingkungan, Program Kemitraan BUMN adalah program untuk meningkatkan kemampuan usaha kecil agar menjadi tangguh dan mandiri. Program Bina Lingkungan adalah adalah program pemberdayaan kondisi sosial masyarakat oleh BUMN.

32 Lihat lebih lanjut Pasal 11 ayat 3 (p) Undang-Undang Nomor 22 Tahun 2001 tentang Minyak dan Gas Bumi.

33 Lihat lebih lanjut Pasal 47 ayat (1) dan ayat (2), Pasal 53 ayat (1) dan ayat (2), Pasal 54 ayat (1) dan ayat (2), Pasal 55 ayat (1), dan Pasal 68 Undang Nomor 32 Tahun 2009 tentang Perlindungan dan Pengelolaan Lingkungan Hidup.

34 Lihat lebih lanjut Pasal 65 ayat (2) huruf b Undang-Undang Nomor 21 Tahun 2014 tentang Panas Bumi.

35 Lihat lebih lanjut Pasal 74 Undang-Undang Nomor 40 Tahun 2007 tentang Perseroan Terbatas.

36 Badan Pembinaan Hukum Nasional Departemen Hukum dan HAM, Op. cit, hlm. 34. 
seimbang, dan sesuai dengan lingkungan, nilai, norma, dan budaya masyarakat setempat. ${ }^{37}$

Dari beberapa peraturan perundangundangan yang mengatur terkait CSR seperti telah disebutkan sebelumnya, tidak ada 1 (satu) pasal pun yang memberikan kewenangan bagi Pemerintahan Daerah untuk mengatur CSR. Sehingga tidak ada dasar hukum Pemerintahan Daerah mengatur CSR dalam Perda, apalagi menjadikan CSR sebagai salah satu komponen pendapatan daerah seperti yang terjadi: di Provinsi Sulawesi Tengah, dana CSR dicantumkan dalam APBD Perubahan 2016 sebagai dana hibah ${ }^{38}$; di Kota Surakarta dicantumkan dana CSR dalam APBD 2017 sebagai dana yang bersifat non budgetary ${ }^{39}$; di Kabupaten Jeneponto, Ketua Baleg DPRD Kabupaten Jeneponto mengatakan untuk peningkatan PAD telah lahir 3 (tiga) Perda, salah satunya Perda CSR, namun tidak dijalankan, kalau Perda CSR dijalankan PAD akan meningkat, sebab CSR 2\% dari total keuntungan perusahaan harus diperoleh daerah ${ }^{40}$; dan di Kota Pekanbaru, anggota DPRD Kota Pekanbaru mengatakan salah satu upaya agar Pemko Pekanbaru meningkatkan sumber PAD yakni

37 Perseroan dalam Peraturan Pemerintah Nomor 47 Tahun 2012 tentang Tanggung Jawab Sosial dan Lingkungan Perseroan Terbatas jauh lebih luas jika dibandingkan dengan perseroan dalam Undang-Undang Nomor 40 Tahun 2007 tentang Perseroan Terbatas. Dalam Peraturan Pemerintah Nomor 47 Tahun 2012 tentang Tanggung Jawab Sosial dan Lingkungan Perseroan Terbatas, perseroan yaitu yang kegiatan usahanya di bidang dan/atau berkaitan dengan sumber daya alam diwajibkan untuk melaksanakan tanggung jawab sosial dan lingkungan. Lahirnya PP 47/2012 ini untuk:

1. meningkatkan kesadaran Perseroan terhadap pelaksanaan tanggung jawab sosial dan lingkungan di Indonesia;

2. memenuhi perkembangan kebutuhan hukum dalam masyarakat mengenai tanggung jawab sosial dan lingkungan; dan

3. menguatkan pengaturan tanggung jawab sosial dan lingkungan yang telah diatur dalam berbagai peraturan perundang-undangan sesuai dengan bidang kegiatan usaha Perseoan yang bersangkutan.

Adapun Pengaturan dalam Peraturan Pemerintah Nomor 47 Tahun 2012 tentang Tanggung Jawab Sosial dan Lingkungan Perseroan Terbatas meliputi:

1. Tanggung jawab sosial dan lingkungan yang dilakukan oleh Perseroan dalam menjalankan kegiatan usahanya di bidang dan/atau berkaitan dengan sumber daya alam berdasarkan Undang-Undang;

2. Pelaksanaan tanggung jawab sosial dan lingkungan dilakukan di dalam ataupun di luar lingkungan Perseroan;

3. Tanggung jawab sosial dan lingkungan dilaksanakan berdasarkan rencana kerja tahunan yang memuat rencana kegiatan dan anggaran yang dibutuhkan untuk pelaksanaannya;

4. Pelaksanaan tanggung jawab sosial dan lingkungan disusun dengan memperhatikan kepatutan dan kewajaran;

5. Pelaksanaan tanggung jawab sosial dan lingkungan wajib dimuat dalam laporan tahunan Perseroan untuk dipertanggungjawabkan kepada RUPS;

6. Penegasan pengaturan pengenaan sanksi Perseroan yang tidak melaksanakan tanggung jawab sosial dan lingkungan; dan

7. Perseroan yang telah berperan dan melaksanakan tanggung jawab sosial dan lingkungan dapat diberikan penghargaan oleh instansi yang berwenang.

38 Dana CSR Jadi Hibah dan Masuk APBD, KPK Diminta Usut Gubernur Longky Djanggola, http://www.aktual.com/ dana-csr-jadi-hibah-dan-masuk-apbd-kpk-diminta-usut-gubernur-longky-djanggola/ (diakses 1 Oktober 2018). Dana CSR Dijadikan PAD, http://realitanusantara.blogspot.com/2011/04/dana-csr-dijadikan-pad.html (diakses 1 Oktober 2018).

39 Lebihi Target, Pendapatan Daerah Surakarta 2017 Capai 100,33\%, https://jatengprov.go.id/beritadaerah/ lebihi-target-pendapatan-daerah-surakarta-2017-capai-10033/ (diakses 1 Oktober 2018).

40 Pemkab Abaikan Perda Peningkatan PAD, Segini Kerugian Daerah Menurut Ketua Baleg DPRD Jeneponto, http:// makassar.tribunnews.com/2017/09/11/pemkab-abaikan-perda-peningkatan-pad-segini-kerugian-daerahmenurut-ketua-banggar-dprd-jeneponto (diakses 1 Oktober 2018). 
mengesahkan ranPerda $\operatorname{CSR}^{41}$, selain itu juga menurut Wakil Ketua DPRD Kota Pekanbaru pada saat pembahasan rancangan Perda CSR, bahwa dana CSR bisa dibelanjakan untuk meubeller sekolah, ruang kelas baru atau infrastruktur, sehingga bisa menjadi sumber PAD baru bagi Kota Pekanbaru.

Pengaturan CSR tersebut tentu memberatkan pengusaha, sebab menimbulkan pungutan ganda yang harus ditanggung perusahaan di daerah. Namun beberapa Pemerintahan Daerah bersikukuh menerbitkan Perda CSR, seperti yang telah disampaikan sebelumnya. Menurut pengamatan Rahmatullah ${ }^{42}$ munculnya Perda CSR karena 4 (empat) kemungkinan: pertama, ada kesan pemerintah daerah (pemda) berupaya membagi beban tanggung jawab pembangunan kepada perusahaan; kedua, ada upaya meraup dana untuk pembangunan daerah yang bersumber dari pihak ketiga; ketiga, pemda berupaya mengelola program CSR satu atap yang dikoordinir oleh pemda, walaupun belum jelas pola dan tata laksananya; keempat, pihak perusahaan tidak serius dalam mendesain dan melaksanakan program CSR.

Sebagaimana telah disampaikan sebelumnya, Pemerintahan Daerah ketika menyusun Perda diselimuti semangat untuk memperoleh sebanyak mungkin pendapatan daerah. Hal ini merupakan imbas negatif dari otonomi daerah, sehingga beberapa kebijakan yang dikeluarkan oleh pemerintahan daerah namun tidak sepenuhnya dilatarbelakangi oleh kajian terhadap kebutuhan masyarakat maupun unsur pemangku kepentingan (stakeholder) lain, yang pada akhirnya tidak memberikan dampak manfaat secara langsung ${ }^{43}$, misalnya dengan maraknya pembuatan Perda CSR yang tidak ada dasar hukum yang mensahkan pembuatan Perda CSR tersebut.

Selain tidak sesuai dengan iklim kemudahan berusaha, keberadaan Perda CSR akan yang menimbulkan ekonomi biaya tinggi yang akan menghambat laju investasi di daerah. Namun, masih banyak Perda CSR yang belum dibatalkan maupun dicantumkan dalam program pembentukan Perda. Perda CSR menjadi penghambat laju investasi di daerah sebab Perda CSR akan menimbulkan kewajiban ganda bagi pengusaha/perusahaan yang harus dibayar selain pajak. Tentunya hal tersebut menjadi komponen penambah bagi perusahaan dalam memproduksi suatu barang/jasa. Tidak mungkin pengusaha tidak menghitungnya ke dalam biaya produksi barang/jasa, sebab tidak ada pengusaha yang menginginkan kerugian, sehingga tentu akan memasukkannya dalam biaya produksi barang/jasa tersebut. Secara otomatis juga memberi pengaruh terhadap harga barang/jasa yang dijual ke pasar. Kenaikan harga barang/jasa yang dijual ke pasar akan berpengaruh terhadap permintaan terhadap barang/jasa tersebut, bila permintaan terhadap barang/jasa tersebut sedikit, maka laba perusahaan tentu akan berkurang. Berkurangnya laba perusahaan secara terus menerus tentu akan berpengaruh terhadap kesehatan keuangan perusahaan tersebut, 
yang akan berpotensi menyebabkan pailit. Jika perusahaan pailit maka akan terjadi pemutusan hubungan kerja. Pemutusan hubungan kerja inilah yang menyebabkan pengangguran, dimana dalam kajian kriminologi pengangguran rawan menimbulkan kejahatan.

\section{Kewenangan Pemerintahan Daerah membentuk Perda CSR}

Buchari Zaenun pernah mengatakan jika keberadaan Perda dalam otonomi daerah sangat penting artinya, sebab Perda merupakan konsekuensi logis dari wewenang daerah untuk mengatur dan mengurus rumah tangganya sendiri. ${ }^{44}$ Pendapat tersebut mirip dengan ketentuan Pasal 236 UU 23/2014 yang menyebutkan: "Untuk menyelenggarakan Otonomi Daerah dan Tugas Pembantuan, Daerah membentuk Perda".

Mencermati apa yang dikemukakan oleh Buchari Zaenun tersebut serta ketentuan Pasal 236 UU 23/2014 maka diketahui Perda lahir karena perintah peraturan perundangundangan yang lebih tinggi, otonomi daerah dan tugas pembantuan dan kondisi kekhususan. Inilah 3 (tiga) hal yang memberikan kebebasan bagi Daerah untuk melahirkan Perda. Namun, hal ini bukan berarti Pemerintahan Daerah dengan sebebasnya membentuk Perda, sebab ada rambu-rambu hukum tertentu dalam pembentukan Perda, seperti: asas pembentukan dan asas materi muatan serta asas hukum yang tumbuh dan berkembang dalam masyarakat sepanjang tidak bertentangan dengan prinsip Negara Kesatuan Republik Indonesia, materi muatan Perda haruslah berupa penyelenggaraan otonomi daerah dan tugas pembantuan, atau penjabaran lebih lanjut ketentuan peraturan perundang-undangan yang lebih tinggi, ataupun memuat materi muatan lokal sesuai dengan ketentuan peraturan perundang-undangan.

Namun, apakah memang Pemerintahan Daerah mempunyai kewenangan untuk mengatur CSR dalam suatu Perda. Guna mengetahuinya, setidaknya perlu diuraikan terlebih dahulu mengenai otonomi daerah.

Pada Alinea ke IV Undang-Undang Dasar Negara Republik Indonesia Tahun 1945 disebutkan bahwa:

".... suatu Pemerintahan Negara Indonesia yang melindungi segenap bangsa Indonesia dan seluruh tumpah darah Indonesia dan untuk memajukan kesejahteraan umum, mencerdaskan kehidupan bangsa, dan ikut melaksanakan ketertiban dunia yang berdasarkan kemerdekaan, Perdamaian abadi dan keadilan sosial, ....."

Alinea ke IV inilah yang menjiwai Pasal 18 ayat (5) Undang-Undang Dasar Negara Republik Indonesia Tahun 1945 yang menyebutkan bahwa:

"Pemerintah Daerah menjalankan otonomi seluas-luasnya, kecuali urusan pemerintahan yang oleh undang-undang ditentukan sebagai urusan pemerintah pusat".

Sebagai implementasi dari amanat Pasal 18 ayat (5) Undang-Undang Dasar Negara Republik Indonesia Tahun 1945 maka di dalam UU 23/2014 disebutkan bahwa:

"Otonomidaerah adalah hak, wewenang, dan kewajiban daerah otonom untuk mengatur dan mengurus sendiri urusan pemerintahan

44 Buchari Zaenun, Administrasi dan Manajemen Pemerintah Negara Indonesia Menurut Undang-Undang Dasar 1945, (Jakarta: Haji Mas Agung, 1990), hlm. 5. 
dan kepentingan masyarakat setempat sesuai dengan peraturan perundang-undangan". ${ }^{45}$

Dalam makalahnya, Marzuki mengatakan bahwa otonomi daerah harus dimaknai dengan pemberian kebebasan dan kemandirian (verijheid en zelfstandigheid) untuk mengatur dan mengurus rumah tangga sendiri atas sebagian urusan pemerintahan sesuai dengan peraturan perundang-undangan. Kebebasan dan kemandirian (verijheid en zelfstandigheid) dalam otonomi yang didasarkan pada UndangUndang Dasar Negara Republik Indonesia Tahun 1945 bukanlah kemerdekaan (independency), akan tetapi kebebasan dan kemandirian (verijheid en zelfstandigheid) dalam ikatan kesatuan yang lebih besar. ${ }^{46}$

Otonomi daerah yang dianut juga bukan merupakan desentralisasi secara total karena terdapat 2 (dua) konsep lain yang juga dilaksanakan bersamaan, yakni dekonsentrasi dan tugas pembantuan ${ }^{47}$ dengan pengertian masing-masing sebagai berikut: ${ }^{48}$

a. Desentralisasi adalah penyerahan Urusan Pemerintahan oleh Pemerintah Pusat kepada daerah otonom berdasarkan Asas Otonomi.

b. Dekonsentrasi adalah pelimpahan sebagian Urusan Pemerintahan yang menjadi kewenangan Pemerintah Pusat kepada gubernur sebagai wakil Pemerintah Pusat, kepada instansi vertikal di wilayah tertentu, dan/atau kepada gubernur dan bupati/wali kota sebagai penanggung jawab urusan pemerintahan umum.

c. Tugas Pembantuan adalah penugasan dari Pemerintah Pusat kepada daerah otonom untuk melaksanakan sebagian Urusan Pemerintahan yang menjadi kewenangan Pemerintah Pusat atau dari Pemerintah Daerah provinsi kepada Daerah kabupaten/ kota untuk melaksanakan sebagian Urusan Pemerintahan yang menjadi kewenangan Daerah provinsi.

Dalam otonomi daerah, Pemerintah Daerah diberikan kesempatan agar berkembang sesuai dengan kemampuan sendiri dan tidak bergantung sepenuhnya pada Pemerintah Pusat. Selain itu dalam otonomi daerah terjadi efisiensi alokasi arus barang publik ke daerah, sekaligus mendekatkan pelayanan kepada masyarakat lokal. Salah satu kewenangan yang dimiliki oleh Pemerintah Daerah yang diberikan konstitusi sebagaimana diatur dalam Pasal 18 ayat (6) Undang-Undang Dasar Negara Republik Indonesia Tahun 1945 adalah pembentukan Perda. Sejak era reformasi hingga tahun 2015 diketahui bahwasanya jumlah Perda provinsi sebanyak 3.177, sedangkan jumlah Perda 
kabupaten/kota sebanyak $25.575 .{ }^{49}$ Banyaknya jumlah Perda tersebut menyiratkan sejak era reformasi Pemerintahan Daerah telah diberikan hak untuk membuat produk hukum daerah, baik untuk hal yang belum ada ketentuannya maupun untuk hal yang sesungguhnya sudah diatur oleh peraturan perundang-undangan di atasnya.

Menurut Jimly Asshiddiqie, Perda adalah salah satu bentuk peraturan pelaksana undangundang. ${ }^{50}$ Perda termasuk dalam hierarki Peraturan Perundang-undangan sebagaimana diatur dalam Pasal 7 ayat (1) UU 12/2011. Sebelum menyusun Perda, haruslah dipahami terlebih dahulu apakah Perda yang akan dibentuk tersebut merupakan Perda yang dibentuk karena kewenangan atribusi ataukah karena delegasi. ${ }^{51}$

Kewenangan Pemerintahan Daerah berdasarkan atribusi merupakan dalam rangka penyelenggaraan otonomi daerah dan tugas pembantuan. Kewenangan atribusi telah diatur dalam UU 23/2014 yaitu sebanyak 32 (tiga puluh dua) urusan pemerintahan. Kewenangan Pemerintahan Daerah berdasarkan delegasi merupakan penjabaran lebih lanjut peraturan perundang-undangan yang lebih tinggi, biasanya dirumuskan dalam dalam undang-undang, peraturan pemerintah, peraturan presiden hingga peraturan menteri dengan frasa "diatur dengan Perda" atau "diatur lebih lanjut dengan Perda".

Setelah mengetahui kewenangan dalam membentuk Perda, maka selajutnya harus mengetahui materi muatan Perda. Secara normatif, materi muatan Perda dapat dilihat dalam ketentuan Pasal 14 UU 12/2011 yang menyatakan bahwa: "Materi muatan Peraturan Daerah Provinsi maupun Peraturan Daerah Kabupaten/Kota berisi materi muatan dalam rangka penyelenggaraan otonomi daerah dan tugas pembantuan serta menampung kondisi khusus daerah dan/atau penjabaran lebih lanjut peraturan perundang-undangan yang lebih tinggi". Ketentuan tersebut senafas dengan ketentuan Pasal 236 ayat (3) dan ayat (4) UU 23/2014 dan Pasal 4 ayat (2) dan ayat (3) Permendagri 80/2015, yang menyebutkan Perda memuat materi muatan: a. penyelenggaraan Otonomi Daerah dan Tugas Pembantuan; dan b. penjabaran lebih lanjut ketentuan peraturan perundang-undangan yang lebih tinggi; selain itu Perda dapat memuat materi muatan lokal sesuai dengan ketentuan peraturan perundangundangan.

Materi muatan dalam rangka penyelenggaraan otonomi daerah dan tugas pembantuan menurut Sihombing mengandung makna bahwa pembentukan Perda harus didasarkan pada pembagian urusan antara Pemerintah, Pemerintah

49 Kementerian Perencanaan Pembangunan Nasional/Badan Perencanaan Pembangunan Nasional, Strategi Nasional Reformasi Regulasi Mewujudkan Regulasi Yang Sederhana Dan Tertib, (Jakarta: Kementerian Perencanaan Pembangunan Nasional/Badan Perencanaan Pembangunan Nasional 2015), hlm. 7.

50 Jimly Asshiddiqie, Perihal Undang-Undang, (Jakarta: Rajawali Pers, 2010), hlm. 16.

51 Dalam Undang-Undang Nomor 30 Tahun 2014 tentang Administrasi Pemerintahan yang dimaksud dengan atribusi adalah pemberian Kewenangan kepada Badan dan/atau Pejabat Pemerintahan oleh Undang-Undang Dasar Negara Republik Indonesia Tahun 1945 atau Undang-Undang, sedangkan delegasi adalah pelimpahan Kewenangan dari Badan dan/atau Pejabat Pemerintahan yang lebih tinggi kepada Badan dan/atau Pejabat Pemerintahan yang lebih rendah dengan tanggung jawab dan tanggung gugat beralih sepenuhnya kepada penerima delegasi. 
Provinsi dan Pemerintah Kabupaten/Kota sebagaimana diatur dalam Undang-Undang tentang Pemerintahan Daerah dan peraturan perundang-undangan sektoral lainnya. ${ }^{52}$ Berkaitan dengan materi muatan daerah dalam rangka menampung kondisi khusus daerah, mengandung makna bahwa Perda sebagai peraturan yang mengabstraksi nilai-nilai masyarakat di daerah yang berisi materi muatan nilai-nilai yang diidentifikasi sebagai kondisi khusus daerah. Berkaitan dengan penjabaran lebih lanjut ketentuan peraturan perundangundangan yang lebih tinggi bermakna bahwa secara yuridis pembentukan Perda bersumber kepada peraturan perundang-undangan yang lebih tinggi. Dengan kata lain pembentukan Perda harus berdasarkan pendelegasian dari peraturan perundang-undangan yang lebih tinggi.

Materi muatan Perda harus diperhatikan oleh Pemerintahan Daerah dalam menyusun Perda, agar Perda yang dihasilkan nantinya benar-benar merupakan kewenangan daerah. Kurangnya pemahaman Pemerintahan Daerah mengenai kewenangannya sering kali mengakibatkan banyaknya Perda yang dipaksakan (tanpa dasar hukum yang jelas), seperti Perda CSR.

Jika berpedoman pada pengertian kewenangan atribusi ataupun kewenangan delegasi untuk membentuk Perda sebagaimana telah diuraikan sebelumnya serta dilihat dari materi muatan Perda, maka Perda CSR bukanlah untuk penyelenggaraan otonomi daerah dan tugas pembantuan ataupun penjabaran lebih lanjut ketentuan peraturan perundangundangan yang lebih tinggi, apalagi untuk memuat materi muatan lokal.

Berdasarkan penelusuran dalam: a) peraturan di bidang otonomi daerah, yakni UU 23/2014 dan UU 33/2004; b) perundangundangan di bidang pembentukan peraturan perundang-undangan, yakni UU 12/2011 dan Permendagri 80/2015; dan c) peraturan perundang-undangan yang mengatur CSR seperti UU 25/2007, UU 40/2007, UU 22/2001, UU 32/2009, UU 21/2014, PP 47/2012, serta PermenBUMN 09/MBU/07/2015, diketahui ternyata CSR bukan kewenangan Pemerintahan Daerah. Kewenangan CSR merupakan kewenangan Pemerintah Pusat yang secara tegas dinyatakan dalam Pasal 74 ayat (4) UU 40/2007 yang menyatakan "Ketentuan lebih lanjut mengenai Tanggung Jawab Sosial dan Lingkungan diatur dengan Peraturan Pemerintah".

Bahkan MK dalam Putusan MK Nomor 53/ PUU-VI/2008 berpendapat bahwa pemerintah daerah tidak dapat mengeluarkan Perda yang berkenaan dengan CSR, sebab perintah berdasarkan Pasal 74 ayat (4) UU 40/2007 adalah hanya diatur dengan PP. ${ }^{53} \mathrm{Hal}$ tersebut dapat dilihat sebagai berikut:

".............Pasal 74 ayat (4) UU 40/2007 dengan jelas menentukan bahwa ketentuan lebih lanjut mengenai TJSL diatur dengan Peraturan Pemerintah;

Eka N.A.M. Sihombing, Pembentukan Peraturan Daerah Partisipatif, (Malang: Intelgensia Media, 2018), hlm. 51.

53 Meskipun putusan Mahkamah Konstitusi ini yang dibacakan dalam sidang terbuka tanggal 15 April 2009 bukan untuk menguji kewenangan Pemerintah Daerah di bidang CSR, namun putusan ini bermanfaat untuk dijadikan referensi bagi eksekutif dan legislatif daerah ketika hendak menyusun perda tentang CSR. Hemat penulis putusan Mahkamah Konstitusi ini justru menegaskan kembali jika kewenangan di bidang CSR merupakan kewenangan Pemerintah Pusat, sebagaimana yang dimaksudkan dalam ketentuan Pasal 74 ayat (4) Undang-Undang Nomor 40 Tahun 2007 tentang Perseroan Terbatas. 
Bahwa dengan telah diatur TJSL berdasarkan Pasal 74 ayat (4) UU 40/2007 maka sudah jelas pemerintah daerah tidak dapat mengeluarkan Peraturan Daerah yang berkenaan dengan TJSL, sebab perintah Undang-Undang berdasarkan Pasal 74 ayat (4) bersifat imperatif yaitu hanya diatur dengan Peraturan Pemerintah".

Perintah Pasal 74 ayat (4) UU 40/2007 bersifat imperatif, yaitu kaidah hukum yang harus ditaati, bisa juga diartikan hukum yang dalam keadaan kongkret harus ditaati atau hukum yang tidak boleh di tinggalkan oleh para pihak dan harus diikuti ${ }^{54}$, sehingga tertutup pintu bagi daerah untuk mengatur CSR dalam Produk Hukum Daerah. Dengan adanya PP 47/2012, lantas bagaimana dengan beberapa Pemerintahan Daerah yang telah menetapkan Perda tentang CSR.

Untuk mengetahuinya, terlebih dahulu harus dipahami mengenai hierarki peraturan perundang-undangan. Hierarki peraturan perundang-undangan dalam penjelasan Pasal 7 ayat (2) UU 12/2011 adalah penjenjangan setiap jenis Peraturan Perundang-undangan yang didasarkan pada asas bahwa Peraturan Perundang-undangan yang lebih rendah tidak boleh bertentangan dengan Peraturan Perundang-undangan yang lebih tinggi. Hierarki tersebut mengandung makna bahwa peraturan yang lebih rendah tidak boleh bertentangan dengan peraturan yang lebih tinggi.

Hierarki peraturan perundang-undangan yang diatur dalam UU 12/2011 tersebut diadopsi dari teori stufenbau (stufenbau des rechts theorie) yang dikemukakan oleh Hans
Kelsen. Menurut Hans Kelsen norma yang lebih rendah ditentukan oleh norma yang lebih tinggi, demikian seterusnya dan bahwa ini regrus diakhiri oleh suatu paling tinggi, norma dasar menjadi pertimbangan bagi kebenaran keseluruhan tata hukum. Teori Stufenbau milik Hans Kelsen diilhami dari pendapat muridnya yang bernama Adolf Merkl yang mengemukakan bahwa suatu norma hukum itu selalu mempunyai dua wajah (das Doppelte Rechsantliz). Lebih lanjut menurut Adolf Merkl, suatu norma hukum itu ke atas ia bersumber dan berdasar pada norma yang diatasnya, tetapi ke bawah ia juga menjadi dasar dan menjadi sumber bagi norma hukum dibawahnya sehingga suatu norma hukum itu mempunyai masa berlaku (rechtskraht) yang relatif oleh karena masa berlakunya suatu norma hukum itu tergantung pada norma hukum yang berada diatasnya sehingga apabila norma hukum yang berada diatasnya dicabut atau dihapus, maka norma-norma hukum yang berada di bawahnya tercabut atau terhapus. ${ }^{55}$ Teori stufenbau juga diadopsi dalam ketentuan Pasal 250 ayat (1) UU 23/2014 yang menyebutkan: "Perda dan Perkada sebagaimana dimaksud dalam Pasal 249 ayat (1) dan ayat (3) dilarang bertentangan dengan ketentuan peraturan perundangundangan yang lebih tinggi, kepentingan umum, dan/atau kesusilaan".

Hierarki peraturan perundang-undangan secara kontekstual berintikan 3 (tiga) asas mendasar dalam hukum perundang-undangan yaitu: asas lex superior derogat lex inferior, lex specialist derogat lex generalis, lex posterior

\footnotetext{
54 Lihat lebih lanjut Purnandi Purbacaraka dan Soerjono Soekanto, Perihal Kaedah Hukum, (Bandung: Citra Aditya Bakti, 1989), hlm. 49.

55 Rachmat Trijono, Dasar-Dasar Ilmu Pengetahuan Perundang-undangan, (Jakarta: Papas Sinar Sinanti, 2013), hlm. 49.
} 
derogat lex priori. $^{56}$ Sehingga bila hierarki dipegang teguh dalam setiap pembentukan peraturan perundang-undangan, maka dengan sendirinya ketiga asas hukum perundangundangan tersebut tidak dilanggar, yang akan berimbas pada terciptanya keharmonisan peraturan perundang-undangan yang dibentuk dengan berbagai peraturan perundangundangan yang telah ada yang levelnya lebih tinggi maupun yang levelnya setara. Oleh karena itu setiap Perda tidak boleh bertentangan dengan peraturan perundang-undangan yang lebih tinggi, hal ini telah diamanatkan dalam UU 12/2011 bahwa dalam membentuk peraturan perundang-undangan (dibaca Perda) harus dilakukan berdasarkan asas pembentukan perturan perundang-undangan yang baik, diantaranya asas kesesuaian antara jenis, hierarki, dan materi muatan. ${ }^{57}$

Perda CSR telah melanggar asas kesesuaian antara jenis, hierarki, dan materi muatan, sehingga apabila Perda CSR tersebut dipertahankan maka dikhawatirkan banyak perusahaan akan hengkang karena Perda CSR membuat pengusaha terkekang. ${ }^{58}$ Selain itu adanya Perda CSR justru akan melegitimasi bentuk-bentuk baru korupsi59, yaitu dengan dalih sumbangan Pemerintahan Daerah memungut sumbangan dari perusahaan untuk melakukan kegiatan-kegiatan tertentu.

Sejatinya fungsi Perda adalah: 60 a. Sebagai instrumen kebijakan untuk melaksanakan otonomi daerah dan tugas pembantuan, sebagaimana diamanatkan dalam Undang-Undang Dasar Negara Republik Indonesia Tahun 1945 dan UndangUndang tentang Pemerintahan Daerah;

b. Merupakan peraturan pelaksanaan dari peraturan perundang-undangan yang lebih tinggi. Berkaitan dengan fungsi inilah Perda tunduk pada ketentuan hierarki peraturan perundang-undangan, sehingga Perda tidak boleh bertentangan dengan peraturan perundang-undangan yang lebih tinggi;

c. Sebagai penampung kekhususan dan keragaman serta penyalur aspirasi masyarakat di daerah, namun tetap dalam koridor Negara Kesatuan Republik Indonesia yang berlandaskan Pancasila dan UndangUndang Dasar Negara Republik Indonesia Tahun 1945;

d. Sebagai alat pembangunan dalam meningkatkan kesejahteraan daerah.

Dengan demikian ditinjau dari konsep otonomi daerah di Indonesia, Pemerintahan Daerah tidak boleh membentuk Perda CSR dengan dalih apapun, sebab pengaturan CSR bukanlah kewenangan daerah. Pelaksanaan CSR merupakan mandatory karena telah diatur dalam beberapa regulasi pusat yang berkaitan dengan CSR tanpa mendelegasikan kepada Pemerintahan Daerah untuk mengatur CSR. 


\section{Penutup}

Keberadaan Perda CSR di tengah iklim kemudahan berusaha bertentangan dengan niat baik Pemerintah untuk mewujudkan kemudahan berusaha. Perda CSR tidak bersahabat dengan investasi, sebab pengaturan CSR dalam Perda hanya akan menimbulkan ekonomi biaya tinggi sehingga akan menghambat laju investasi di daerah, sebab akan melahirkan pungutan ganda yang harus ditanggung oleh pengusaha/ perusahaan disamping pembayaran pajak. Untuk menutupi biaya ganda tersebut maka akan diperhitungkan sebagai komponen tambahan dalam memproduksi suatu barang/ jasa yang tentunya akan mempengaruhi harga jual barang/jasa tersebut, permintaan barang/ jasa tersebut, laba perusahaan, kesehatan keuangan perusahaan, serta jumlah karyawan yang dipekerjakan. Karena itu hendaknya bagi eksekutif dan legislatif di daerah ketika akan membentuk suatu Perda harus terlebih dahulu memahami rambu-rambu hukum dalam pembentukan Perda, seperti kewenangan daerah dan kewenangan pembentukan Perda serta substansi materi yang akan diatur, serta melakukan analisis biaya dan manfaat (cost and benefit analysis) terhadap penyusunan suatu Perda sehingga tidak perlu membuat Perda CSR.

Adapun kedudukan Perda CSR dalam peraturan perundang-undangan adalah bertentangan dengan peraturan lebih tinggi dan harus dibatalkan, sebab tidak ada ketentuan 1 (satu) pasal pun dalam: (a) konsep otonomi daerah yang diatur dalam UU 23/2014 dan UU 33/2004; (b) kewenangan pembentukan Perda yang diatur dalam UU 12/2011 dan Pemendagri 80/2015; dan (c) pengaturan CSR dalam beberapa peraturan perundangundangan yang terkait CSR seperti UU 25/2007, UU 40/2007, UU 22/2001, UU 32/2009, UU
21/2014, PP 47/2012, serta PermenBUMN 09/MBU/07/2015 yang memberikan legalitas bagi Pemerintahan Daerah untuk mengatur CSR dalam Perda. Secara tegas pengaturan CSR merupakan kewenangan Pemerintah Pusat sebagaimana dimaksud pada Pasal 74 ayat (4) UU 40/2007. Hal ini juga diaminkan oleh pendapat MK dalam Putusan MK Nomor 53/ PUU-VI/2008. Karena itu Perda CSR harus segera dicabut oleh Pemerintahan Daerah itu sendiri untuk menciptakan kenyamanan berusaha dalam rangka ease of doing business. Selain itu pengusaha yang keberatan terhadap Perda CSR yang telah ada dapat mengajukan judicial review ke Mahkamah Agung.

\section{Daftar Pustaka}

\section{Buku}

Asshiddiqie, Jimly, Perihal Undang-Undang, (Jakarta: Rajawali Pers, 2010).

Badan Pembinaan Hukum Nasional, Departemen Hukum dan HAM, Tanggung Jawab Sosial Perusahaan, (Jakarta: Departemen Hukum dan HAM, 2009).

Badan Pembinaan Hukum Nasional, Kementerian Hukum dan HAM, Perencanaan Pembangunan Hukum Nasional 2015-2019, (Jakarta: Kementerian Hukum dan HAM, 2014).

Direktorat Jenderal Peraturan Perundang-undangan, Kementerian Hukum dan HAM, Panduan Praktis Memahami Perancangan Peraturan Daerah, (Jakarta: Kementerian Hukum dan HAM, 2011).

Hamidi, Jazim, et. al., Teori \& Hukum Perancangan Perda, (Malang: Universitas Brawijaya Press, 2012).

Marzuki, Peter Mahmud, Penelitian Hukum, (Jakarta: Prenadamedia Group, 2011).

Purbacaraka, Purnandi dan Soerjono Soekanto, Perihal Kaedah Hukum, (Bandung: Citra Aditya Bakti, 1989).

Soekanto, Soerjono dan Sri Mamudji, Penelitian Hukum Normatif Suatu Tinjauan Singkat, (Jakarta: RajaGrafindo Persada, 2007).

Sihombing, Eka N.A.M., Pembentukan Peraturan Daerah Partisipatif, (Malang: Intelgensia Media, 2018). 
Trijono, Rachmat, Dasar-Dasar Ilmu Pengetahuan Perundang-undangan, (Jakarta: Papas Sinar Sinanti, 2013).

Untung, Hendrik Budi, Corporate Sosial Responsibility, (Jakarta: Sinar Grafika, 2008).

Zaenun, Buchari, Administrasi dan Manajemen Pemerintah Negara Indonesia Menurut UndangUndang Dasar 1945, (Jakarta: Haji Mas Agung, 1990).

\section{Makalah/Artikel/Prosiding/Hasil Penelitian}

Badaruddin, "Implementasi Tanggung Jawab Sosial Perusahaan Terhadap Masyarakat Melalui Pemanfaatan Potensi Modal Sosial: Alternatif Pemberdayaan Masyarakat Miskin Di Indonesia", Pidato Pengukuhan Jabatan Guru Besar Tetap dalam Bidang Ilmu Sosiologi Perkotaan pada Fakultas IImu Sosial dan IImu Politik Universitas Sumatera Utara 12 April 2008, (Medan: Universitas Sumatera Utara, 2008).

Firdaus, M. Azis, "Kemitraan Pemerintah Dan Swasta Dalam Pembangunan Sumber Daya Manusia Melalui Implementasi CSR", dalam Proceeding Simposium Nasional Otonomi Daerah: Best Practices Dalam Penyelenggaraan Otonomi Daerah, (Serang: FISIP Untirta dan Laboratorium Administrasi Negara FISIP Untirta, 2011).

Hasadi, Hasa Noor et al., "Pengaruh Program Corporate Social Responsibility (CSR) PT. Sebuku Iron Lateritic Ores (PT. SILO) Terhadap Tingkat Pendapatan Masyarakat Di Desa Tanjung Mangkuk, Kecamatan Pulau Sebuku, Kabupaten Kotabaru", JPG (Jurnal Pendidikan Geografi) (Vol. 1, No 1 Juli 2014).

Marzuki, "Peranan Program Legislasi Daerah/ Program Pembentuksan Peraturan Daerah Dalam Proses Pembentukan Peraturan Daerah", (makalah disampaikan dalam Bimbingan Teknis Program Legislasi Daerah, Medan, 23 April 2015).

Rahmatullah, "CSR dan Kepentingan Pemerintah Daerah", dalam Proceeding Simposium Nasional Otonomi Daerah: Best Practices Dalam Penyelenggaraan Otonomi Daerah, (Serang: FISIP Untirta dan Laboratorium Administrasi Negara FISIP Untirta, 2011).

Simatupang, Taufik H, "Peran Perancang Peraturan Perundang-Undangan Kantor Wilayah Kementerian Hukum dan HAM Dalam Rangka Harmonisasi Peraturan Daerah", Jurnal IImiah Kebijakan Hukum (Vol. 11 No. 1 Maret 2017).

\section{Internet}

Tentang Kemudahan Berusaha, http:// pembaruanperadilan.net/kemudahanberusaha/ (diakses 13 Agustus 2018).

Naik 19 Peringkat, Kemudahan Berusaha RI Di Atas China dan India, https://finance.detik. com/berita-ekonomi-bisnis/d-3708649/naik19-peringkat-kemudahan-berusaha-ri-di-ataschina-dan-india (diakses 13 Agustus 2018).

Daftar Perda/Perkada Dan Peraturan Menteri Dalam Negeri Yang Dibatalkan/Revisi, https://www.kemendagri.go.id/media/ filemanager/2016/06/21/b/a/batal_Perda_21_ juni_2016.pdf (diakses 3 Oktober 2018).

Presiden Umumkan Pembatalan 3.143 Perda Bermasalah, https://www.kemendagri.go.id/ blog/4334-Presiden-Umunkan-Pembatalan3143-Perda-Bermasalah (diakses 3 Oktober 2018).

Pakai Dana CSR, Ridwan Kamil Diingatkan Soal Serapan APBD, https://nasional.tempo.co/ $\mathrm{read} / 670014 /$ pakai-dana-csr-ridwan-kamildiingatkan-soal-serapan-apbd/full\&view=ok (diakses 4 Oktober 2018).

Memanjakan Warga Jakarta Dengan ProdukProduk CSR, https://megapolitan.kompas.com/ $\mathrm{read} / 2015 / 09 / 05 / 06030031 / M e m a n j a k a n$. Warga.Jakarta.dengan.Produk-produk.CSR (diakses 4 Oktober 2018).

Pemkab Garap Perda CSR, http://pedomanbengkulu. com/2016/12/pemkab-garap-Perda-csr/ (diakses 2 Oktober 2018).

Dana CSR Jadi Hibah Dan Masuk APBD KPK Diminta Usut Gubernur Longky Djanggola, http://www. aktual.com/dana-csr-jadi-hibah-dan-masukapbd-kpk-diminta-usut-gubernur-longkydjanggola/ (diakses 1 Oktober 2018).

Dana CSR Dijadikan PAD, http://realitanusantara. blogspot.com/2011/04/dana-csr-dijadikan-pad. html (diakses 1 Oktober 2018).

Lebihi Target, Pendapatan Daerah Surakarta 2017 Capai 100,33\%, https://jatengprov.go.id/ beritadaerah/lebihi-target-pendapatan-daerahsurakarta-2017-capai-10033/ (diakses 1 Oktober 2018).

Pemkab Abaikan Perda Peningkatan PAD, Segini Kerugian Daerah Menurut Ketua Baleg DPRD Jeneponto, http://makassar.tribunnews. com/2017/09/11/pemkab-abaikan-Perdapeningkatan-pad-segini-kerugian-daerah- 
menurut-ketua-banggar-dprd-jeneponto (diakses 1 Oktober 2018).

Pemko Lirik Dana CSR Sebagai Sumber PAD, https:// www.riaumandiri.co/read/detail/52555/ pemko-lirik-dana-csr-sebagai-sumber-pad.html (diakses 1 Oktober 2018).

Pengusaha Terancam Kabur Dari Tangsel, Kelola CSR Tidak Perlu Perda, http://tangselpos. co.id/2015/04/29/pengusaha-terancam-kaburdari-tangsel-kelola-csr-tidak-perlu-Perda/ (diakses 5 Maret 2016).

Meregulasi CSR: Keluar Dari Jebakan Mengepul Uang, http://www.academia.edu/21596708/ MEREGULASI_CSR_Keluar_Dari_Jebakan_ Mengepul_Uang_(diakses 1 Februari 2016).

\section{Peraturan Perundang-undangan}

Undang-Undang Nomor 22 Tahun 2001 tentang Minyak dan Gas Bumi.

Undang-Undang Nomor 33 Tahun 2004 tentang Perimbangan Keuangan Antara Pemerintah Pusat dan Pemerintahan Daerah.

Undang-Undang Nomor 40 Tahun 2007 tentang Perseroan Terbatas.
Undang Nomor 32 Tahun 2009 tentang Perlindungan dan Pengelolaan Lingkungan Hidup.

Undang-Undang Nomor 12 Tahun 2011 tentang Pembentukan Peraturan Perundang-undangan.

Undang-Undang Nomor 21 Tahun 2014 tentang Panas Bumi.

Undang-Undang Nomor 23 Tahun 2014 tentang Pemerintahan Daerah sebagaimana telah diubah beberapa kali terakhir dengan Undang-Undang Nomor 9 Tahun 2015 tentang Perubahan Kedua Undang-Undang Nomor 23 Tahun 2014 tentang Pemerintahan Daerah.

Peraturan Pemerintah Nomor 47 Tahun 2012 tentang Tanggung Jawab Sosial dan Lingkungan Perseroan Terbatas.

Peraturan Menteri Dalam Negeri Nomor 80 Tahun 2015 tentang Pembentukan Produk Hukum Daerah.

Peraturan Menteri BUMN Nomor PER-09/ $\mathrm{MBU} / 07 / 2015$ tentang Program Kemitraan Badan Usaha Milik Negara Dengan Usaha Kecil dan Program Bina Lingkungan.

Putusan Mahkamah Konstitusi Nomor 53/PUU$\mathrm{VI} / 2008$. 
"Halaman ini dikosongkan" 